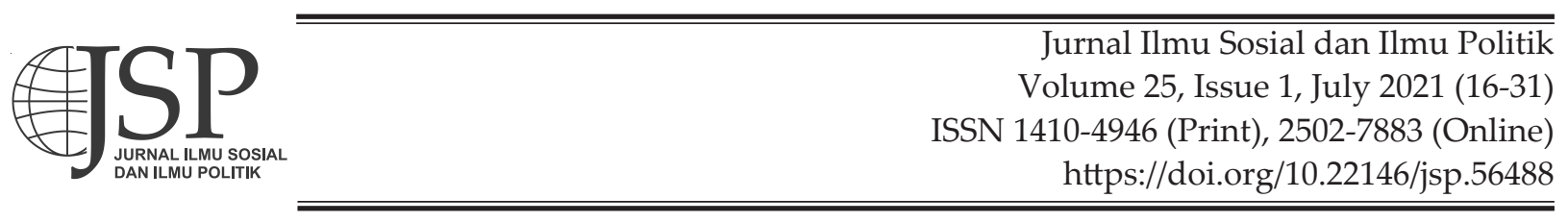

\title{
Content Analysis of Social Media: Public and Government Response to COVID-19 Pandemic in Indonesia
}

\author{
Gugun Geusan Akbar' ${ }^{1}$, Dede Kurniadi ${ }^{2}$, Nita Nurliawati ${ }^{3}$ \\ ${ }^{1}$ Department of Social and Political, Universitas Garut, Indonesia (email: gugun.ga@fisip.uniga.ac.id) \\ ${ }^{2}$ Department of Informatics, Sekolah Tinggi Teknologi Garut, Indonesia \\ ${ }^{3}$ Department of State Development Administration, Politeknik LAN Bandung, Indonesia
}

\begin{abstract}
Nowadays, the use of social media to analyze disaster responses has become important. However, its application to support decision-making by the Government during disasters still present significant challenges. This article offers a complete analysis of the response of the public and the Government in dealing with the COVID-19 Pandemics in Indonesia. The content analysis uses to analyze the tweet post on Twitter to determine the public and government response. Data was collected from public and government tweets on Twitter and producing 11,578 community tweets from the public and 958 tweets from the government account. This data was collected from $2^{\text {nd }}$ March until $15^{\text {th }}$ April 2020. Public comments are sorted into six categories of comments, that is fate, logic, government mention, worry, scientist, and impression, while sentiments are classified as positive, negative, and neutral. Government comments are sorted into eight categories, namely information, education, operating, warnings, resources provision, volunteer recruitment, and rumors management. The results showed that the public encourages and supports the Government to cope with a pandemic think rationally and logically in dealing with this Pandemic. In addition, the study indicates that the Government has not used social media as a medium for communicating with the public. The quality of government response is not good, especially in the categories of information on operations, warnings, resources provision, recruitment of volunteers, and rumors management. The implication of this study suggests how the data might be useful for the Government in delivering information during the Pandemic.
\end{abstract}

Keywords:

coronavirus; sentiment analysis; social media

\section{Introduction}

Since its appearance in December 2019, coronavirus (COVID-19) has spread not only in China but quickly spread throughout the world. The disease is highly contagious, and on February 11, 2020, two months since the first case was discovered, 44,672 confirmed infection cases and 1,113 deaths had been reported in mainland China (Z. Wu \& McGoogan, 2020). Outside China, there have been 100,000 people infected from 100 countries, so then WHO, on March 11, 2020, established COVID-19 as a Pandemic. The status of a global pandemic or epidemic indicates that the spread of COVID-19 took place so fast that almost no country in the world could ensure that they avoided COVID-19 (Sohrabi et al., 2020).

Indonesia has the fourth-largest population in the world, has considerable potential affected by this COVID-19 epidemic (De Salazar, Niehus, Taylor, Buckee, \& Lipsitch, 2020). Since the first case was announced in March 2020, up to April 2020, there have been 7,180 positive cases with 765 deaths in Indonesia (Worldmeter, 2020). With such conditions, disaster management becomes crucial for Indonesia in tackling the COVID-19 Pandemic. 
The researchers responded to the COVID-19 Pandemic with various efforts made, they seemed to race with time to find a vaccine and how to fight this COVID-19 (S. F. Ahmed, Quadeer, \& McKay, 2020; Caddy, 2020; Gao, Tian, \& Yang, 2020; Li, Geng, Peng, Meng, \& Lu, 2020; Liu et al., 2020; Prompetchara, Ketloy, \& Palaga, 2020). However, most experts agree it will be 12-18 months before a coronavirus disease (COVID-19) vaccine is approved, and even longer before one is available on a wide scale (Thompson, Barber, \& Bourget, 2018). With the time required for the vaccine to be applied, governments in all countries must have a strategy that can suppress this COVID-19 outbreak.

Nowadays, social media is a source of additional information increasingly being recognized and receiving attention in disaster management (Wukich, 2016). Social media is not only a platform for sharing people's personal lives. Still, it can also examine public opinions and perceptions, which can compare with public comments collected by traditional approaches (e.g., Questionnaires) (de Albuquerque, Herfort, Brenning, \& Zipf, 2015)(de Albuquerque et al., 2015). Combined with spatial-temporal information collected from social media, public opinions and feelings about disasters mined from social media can help government decisions and help people better understand the state of disaster events (Wang \& Ye, 2018).

In dealing with COVID-19, two crucial aspects must understand, namely the opinions and responses of the people and how the Government responds. From a broader perspective of overcoming the COVID-19 pandemic outbreak (Olapegba et al., 2020), (Kaila, R.P. \& Prasad, 2020), (Wang \& Ye, 2018) justify the importance of social media as a platform for conducting surveys and mining data online. If used responsibly and appropriately, social media can provide information disseminating quickly and effectively.
Researchers have offered various methods of utilizing social media for disaster management. This method can be seen from two perspectives, namely Government and society. From a public perspective, (Han, Wang, Zhang, \& Wang, 2020) offer temporal and spatial analysis to explores public opinion in the early stages of COVID-19 in China by analyzing Sina-Weibo (a microblogging system such as Twitter in China) in terms of space, time, and content. (W. Ahmed, Vidal-Alaball, Downing, \& Seguí, 2020) offers a method to find online referral sources. (Merkley et al., 2020) examines the Elite and Public Response to the COVID-19 Pandemic in Canada. In this study, the methods offered are aggregate level analysis and individual analysis.

From the perspective of the Government's response, (La et al., 2020) offers methods based on chronology analysis, policy response, media communication, while (Han \& Wang, 2019) offers methods based on Time Series Analysis, Time-Series and Topic Extraction and Classification. However, existing studies have not explored prosperous public sentiments in social media content and how the Government responds to disasters that happened.

This research provides a word cloud model that contains the public sentiments and government responses. This study classifies tweets from Twitter social media using sentiment analysis as a part of the text mining technique (Branz \& Brockmann, 2018). There is much previous research of sentiment analysis from social media to get important information, among others: (1) sentiment analysis to analyze the satisfaction of citizens in public service (Akinboade, Kinfack, \& Mokwena, 2012); (2) sentiment analysis of film review (Amrullah, Sofyan Anas, \& Hidayat, 2020; Maylawati, Mudyawati, Wahisyam, \& Maulana, 2021); (3) sentiment analysis to review product quality (Gunawan, Pratiwi, \& Pratama, 2018); (4) sentiment analysis of government policy such as traffic control policy (Ruhyana, 2019) and 
bureaucratic service (Muliawaty, Alamsyah, Salamah, \& Maylawati, 2019); and so on

Based on that previous research, this study used the sentiment analysis technique to understand the disaster situation based on the response from the Government and public. The contribution of this research is to offer a method that can simultaneously identify responses from Government and society, which can help better understand disaster management. The study, though in its preliminary and subject to changes as the disease progresses, may nonetheless, and helpful for better understanding public and Government response so specific steps can fight the Pandemic. Therefore, this research aims to find a public and Government response and sentiment about the pandemic COVID-19 from Twitter.

\section{Literature Review}

Big Data from social media can be used in responding to crises for various purposes such as communicating with the public during emergency response and recovery, detecting early warning messages, engaging public services, communicating with other organizations involved in disaster management, monitoring messages sent by parties other humanitarian organizations and the general public (Al Tamimi \& Dwivedi, n.d.; Ragini, Anand, \& Bhaskar, 2018; Rodrigues, Rao, \& Chiplunkar, 2018; Zaki, 2018).

In social media also contain the public opinion or public response to an issue. Public response referred to here is a reaction or response to an issue. This public response can be classified into the sentiment, among others positive sentiment, negative sentiment, and neutral (Branz \& Brockmann, 2018; X. Wu, Zhu, Wu, \& Ding, 2014). While the governance response is an answer or reply or feedback response referred to public response about an issue.

In natural disaster management, research that utilizes social media as a database has studied patterns of using social media during crises (Dhyani, Thakur, \& Sahu, 2019), Vayansky (2019), (Putra, Khalil, Gunawan, Amin, \& Sutabri, 2018); the results indicate that sentiment analysis can measure changes in user emotions during natural disasters.

Besides research that highlights the spatial and temporal characteristics of social media, scholars explore topics and classify social media texts to increase knowledge about disaster situations. (Vayansky, Kumar, \& Li, 2019) creates topic modeling to express people's emotions when a disaster occurs. In developing the model, topics were classified as Relief, Community, Hurricane, Speculation. This research can be further improved by incorporating sentiment analysis methods for short texts, classifying emoticons and non-textual components such as videos or images, and optimizing data collection and preparation methods.

Research on the role of social media during the Mount Kusatsu-Shirane volcanic disaster was also carried out by (Yamada, 2020), that an inductive category-extraction strategy, the comments sorted into six categories of comments: that referred to volcanic risk perception, on volcanology or volcanologists, with fatalistic perceptions of natural disasters as blameless misfortunes, on eruption predictability, on disaster risk reduction measures implemented by central/ local governments and disaster management agencies, and explaining the phreatic explosion mechanism. This study offers analyzed the content of comments posted on an online news site to investigate the direct responses to volcanology-related topics.

Pastor (2020) examined the quarantine effect during a pandemic in the Philippines by taking data from Twitter by using positive, neutral, and negative sentiments. This research can capture people's feelings during a pandemic through the sentiments expressed.

The Government's response in dealing with disasters is also essential. Government 
responses can categorize into several categories. Research conducted by Sutton, Hughes, St Denis, and Wukich in 2014 has opened up research spaces on government messages often inaccurately proportionately discusses large-scale disaster response efforts, ignoring small-scale incidents and other cross-phase disaster activities (e.g., prevention, mitigation, preparedness, and recovery) (Sutton et al., 2014). This research has offered a warning category for the Government in conveying information to the public. While Hughes et al in 2014 recommend operating, resource provision, and volunteer recruitment (Hughes, St. Denis, Palen, \& Anderson, 2014). Then, Denis et al in 2014 offer information and rumors management (St. Denis, Palen, \& Anderson, 2014). Wukich in 2016 offers rumors management, volunteer recruitment, and education (Wukich, 2016). Some of these categories have been able to describe various messages, with the most common response and preparedness by the Government.

Alguliyev in 2019 examines the Lexical Resource and Dataset Sentiment Analysis for Government Smart Apps Domain (Alguliyev, Aliguliyev, \& Niftaliyeva, 2019). His research presents work done to produce a unique dataset consisting of aspects of government smart application domains and words of opinion. Besides, his research explains the approach taken to measure sentiment scores on expressions of opinion and build the desired lexicon. Annotation and data preparation tools for general use were developed to facilitate the development of lexical resources and SA datasets for the smart government application domain. The research on Sentiment Analysis on Indian Government Schemes Using Twitter data (Rekha, Raksha, Patil, Swaras, \& Rajat, 2019), utilizes data from Twitter by using the Python language code followed by a cleansing process then the creation of words appears. Previous research has been conducted able to increase the knowledge and use of social media in disaster management, and the benefits have been felt. However, in some cases, there are still limitations that open up room for improvement.

In terms of public response, one obstacle in capturing public responses is language. Text from social media is difficult to analyze, as they often contain few words, slang or phrases, videos and images, and emoticons (Hong and Davison, 2010), especially in capturing public responses in languages other than English. It takes complicated steps involving various methods before we cleanly make use of it. Some methods and categorization also have limitations where they can be used only in one condition. For example in Yamada's research did not reveal what people thought about the possibility of predicting other types of eruptions than a phreatic eruption (e.g., magmatic eruptions) as there were no reports on this topic in the news stories on the $2018 \mathrm{Mt}$. Kusatsu-Shirane disaster.

\section{Methods}

In the method used, the methods of sentiment analysis are data collecting, data cleaning, and data analysis. Several researchers have used this method in various sentiment analysis studies. Some researchers offer a more detailed method. Alguliyev et al., 2019 offer social network extraction (SONEX) to add data collection and preprocessing, data classification, social network analysis. One thing needed in SONEX is the need for data access in its processing, and this becomes an obstacle when researchers do not have access to data sources. Meanwhile, Ragini in 2018 offers a more detailed stage: data collection, data storage, data preprocessing, learning \& classification, and presentation. The method offered by Ragini is considered more detailed and easier to implement, especially in emergencies. The methods and categorizations done by previous researchers can be seen in Table 1. Then, this research use word cloud 
Table 1.

Study Comparison of Method, Scope, and Categorized Data

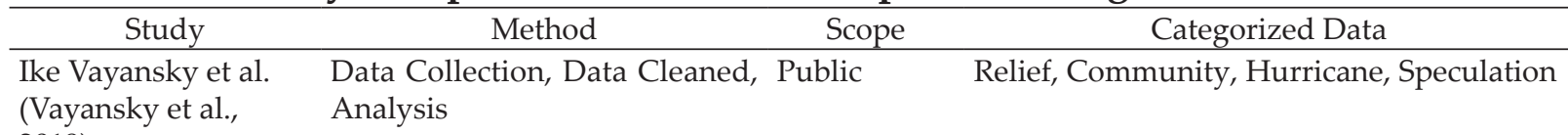

2019)

Ko Yamada (Yamada, Data Collection, Data Cleaned, Public 2020) Analysis

Cherish Kay L Pastor (Pastor, 2020)

J. Rexiline Ragini et al. (Ragini et al., 2018)

Rasim M. Alguliyev et al. (Alguliyev et al., 2019)

Jeannette Sutton et al. Data Collection, Data Analysis (Sutton et al., 2014)

Amanda L. Hughes et al. (Hughes et al., 2014)

Lise Ann St. Denis et al. (St. Dennis et al., 2014)

Clayton Wukich, 2016 (Wukich, 2016) Data Collection, Data Analysis

Data Collection, Data Analysis

Data Collection, Data Cleaned, Public Alysis data preprocessing, learning \&

preprocessing, data

classification, SONEX, social

Government

Government

Data Collection, Data Analysis

Government
Fatalism, Research, Eruption Predictability, Government Attitude Toward Volcanic Disaster, Risk Perception, Scientific Explanation of Eruption, Impression About the Volcanic Disaster

Positive, Neutral, Negative

Food, Water, Medical Emergency, Shelter, Electricity with Positive, Neutral, Negative Sentiments

Government Extraction of Social Networks from The Web, Email, Blogs, Online Social Networking Sites

Guidance, Time, Location, Hazard and Consequence, Source

Cleanup, Closures Damage, Donations Engagement, Evacuation, Preparation, Protocol, Reassurance, Reference, Relief, Response,

Resources, Rumor, Safety, Services, Status, Support, Weather

Government Hyperlinks \& Explicit References, Online Engagement, Protocol, Public, Rumor, Safety, Services, Status

Situational Information, Education, Advisories, Operations, Warnings, And Watches, Hazard Impact, Resource Provision, Commentary, Training and Exercises, Closures, Drills, Conversation Starter, Administration News, Openings, Gamification, Volunteer Recruitment, Evacuations, Intelligence Gathering, Fundraising, Corrections, Rumor Management, Resource Seeking

\section{Source: Compiled by the Author}

model to visualize the frequency of word to help the analysis or interpretation process of public sentiment.

This research offers a step developed from Ragini by combining analysis of public and Government responses. We also offer a categorization divided into a public response categorization, which is also measured by public sentiment, and a government response category. In terms of method, we offer more detailed steps with a simpler level of work. In our categorization, we offer categories considered to be deeper in use in a variety of circumstances.

\section{Applying content analysis}

The proposed sentiment model for the public and Government consists of five phases data collection phase, data storage phase, data preprocessing phase, learning \& 


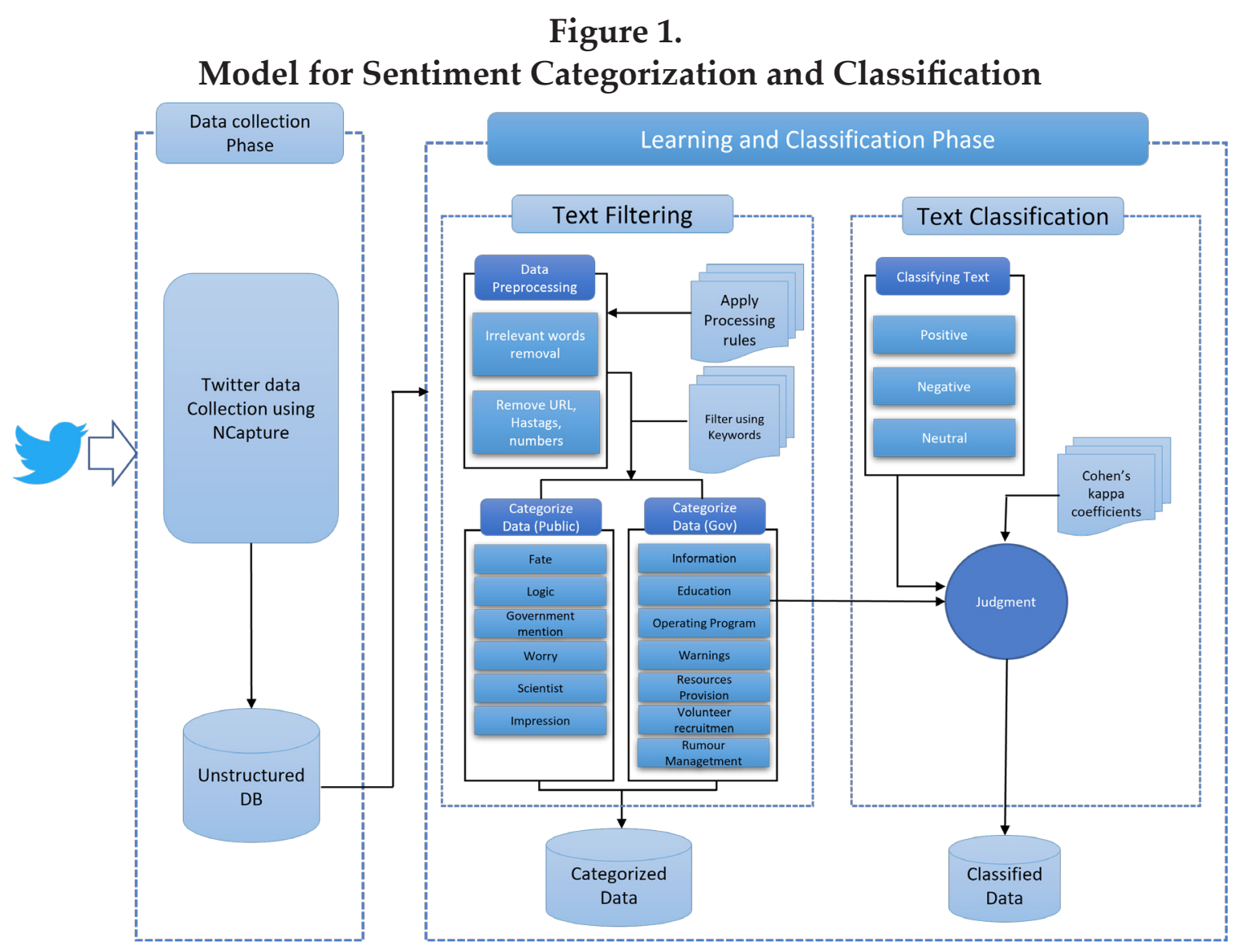

Source: Developed by the Author

classification phase, and presentation phase, adopted from (Ragini et al., 2018). Public response categorization consists of fate, logic, government mention, worries, scientist, and impressions, adopted from (Yamada, 2020). For government response, categorization consists of information, education, operating/program, warnings, research provision, volunteer recruitment, and rumor management, adopted from (Wukich, 2016). Propose of the model can be seen in Figure 1. The model in Figure 1 is the created model of this research that developed from Ragini's research model (Ragini et al., 2018).

\section{Data collection and analysis}

Data was obtained from comments posted on Twitter from March 2 to April 15, 2020. Keywords used "Virus Corona" and "COVID-19" by using NCapture software. Data from the Government was obtained from accounts representing the Government, namely accounts of the President, National Disaster Management Agency, Ministry of Health, Ministry of Finance, Ministry of Internal Affairs, and Ministry of Social Affairs. From the results of data mining, 17,259 comments were consisting of various sources of tweets for filtering. Tweets deemed unsuitable and irrelevant were then eliminated. The filtering results obtained were 11,578 public tweets and 958 government tweets related to "Corona Virus" and "COVID-19".

The next phase is Text Classification, where comments from the public are separated into six categories, namely fate, logic, government mention, worry, scientist, and impression (Yamada, 2020); three classifications of sentiments for the public is positive, negative, neutral (X. Wu et al., 2014). While the government chat categories are sorted into eight categories, namely information, 
education, operating, warnings, resources provision, volunteer recruitment, and rumors management (Wukich, 2016). Consistency and validity test with a Cohens Kappa coefficient was measured with a result of 0.78 (0.05 Standard Deviation) so it can conclude that the measurement results are reliable. The category of public response can see in Table 2.

Table 2.

\section{Public Response Categorized}

\begin{tabular}{|c|c|}
\hline Category & Definition \\
\hline Fate & $\begin{array}{l}\text { Comments that claim that the COVID-19 } \\
\text { outbreak is "an act of God" and nothing } \\
\text { can do to reduce the danger. These } \\
\text { comments reflect people's belief that } \\
\text { everything is due to God's permission }\end{array}$ \\
\hline Logic & $\begin{array}{l}\text { Comments that refer to the opinions } \\
\text { of experts, research results, other } \\
\text { scientific sources. Comments that try } \\
\text { to analyze and provide comments on } \\
\text { the COVID-19 based on these sources }\end{array}$ \\
\hline $\begin{array}{l}\text { Government } \\
\text { Mention }\end{array}$ & $\begin{array}{l}\text { Comments on the Government for } \\
\text { COVID- } 19 \text { disasters: Comments that } \\
\text { link the disaster with the Government's } \\
\text { response to the virus outbreak }\end{array}$ \\
\hline Worry & $\begin{array}{l}\text { Comments expressing anxiety about the } \\
\text { danger of the COVID-19 }\end{array}$ \\
\hline Scientist & $\begin{array}{l}\text { Comments from experts describing the } \\
\text { COVID-19 }\end{array}$ \\
\hline Impression & $\begin{array}{l}\text { Comments include individual shows } \\
\text { with memories and other statements } \\
\text { not included in the five categories } \\
\text { above-for example, about optimism, } \\
\text { seeing disaster with humor, etc. }\end{array}$ \\
\hline
\end{tabular}

Source: modified from Yamada (2020)

Public sentiment is classified as positive, negative, and neutral sentiment (Shull, Jiang, Zhu, \& Zhu, 2019). Supporting or beneficial messages are identified as positive sentiment, and critical or taunting messages are identified as negative sentiment. The "neutral" category includes stories with neutral or mixed tones; for example, "I understand that handling COVID-19 epidemics is difficult, but it must remember that this is the job of the government."

Government response categories can see in the following table 3:
Table 3.

Government Response Categorized

\begin{tabular}{|c|c|}
\hline Category & Definition \\
\hline Information & $\begin{array}{l}\text { A tweet that contains information on } \\
\text { the current situation }\end{array}$ \\
\hline Education & Educational tweet to the public \\
\hline $\begin{array}{l}\text { Operating/ } \\
\text { Program }\end{array}$ & $\begin{array}{l}\text { Tweet about a pandemic } \\
\text { countermeasure program }\end{array}$ \\
\hline Warnings & Tweet about the danger of a pandemic \\
\hline $\begin{array}{l}\text { Resources } \\
\text { Provision }\end{array}$ & Tweet about mobilizing resources \\
\hline $\begin{array}{l}\text { Volunteer } \\
\text { recruitment }\end{array}$ & Tweet about volunteer recruitment \\
\hline $\begin{array}{l}\text { Rumor } \\
\text { Management }\end{array}$ & Tweet picks rumors or hoaxes \\
\hline
\end{tabular}

Source: modified from Wukich (2016).

\section{Results}

The public response can be seen in Table 4. Table 4 shows the impression category has the most frequency $(48.56 \%)$, then the secondhighest category is government mention $(30.60 \%)$, then logic $(8.63 \%)$, worry $(7,06 \%)$, scientist $(4.15 \%)$, and the lowest category is fate $(0.83 \%)$.

Table 4.

Classification of Public Responses

\begin{tabular}{clcc}
\hline ID & \multicolumn{1}{c}{ Categories } & Amount & Percentage \\
\hline A & Fate & 96 & 0,83 \\
B & Logic & 999 & 8,63 \\
C & Government Mention & 3.543 & 30,60 \\
D & Worry & 818 & 7,07 \\
E & Scientist & 480 & 4,15 \\
F & Impression & 5.738 & 49,56 \\
\hline
\end{tabular}

Source: analysis results, data was taken from Twitter from March 2 to April 15, 2020

Table 5 and Figure 2. show public sentiment on the COVID-19 pandemic issue. The results show that the fate category has a higher number of positive sentiments. Logic has a higher negative sentiment. The Government mention has higher negative sentiments, worry has higher positive sentiments, scientists have a higher positive sentiment, and an impression has a higher negative sentiment. 
Table 5.

Categories and Sentiments

\begin{tabular}{lccc}
\hline \multicolumn{1}{c}{ Categories } & Positive & Negative & Neutral \\
\hline Fate & 50 & 12 & 20 \\
Logic & 323 & 334 & 342 \\
Government Mention & 918 & 1.086 & 1.539 \\
Worry & 327 & 183 & 308 \\
Scientist & 232 & 199 & 49 \\
Impression & 1.215 & 2.046 & 2.477 \\
\hline & 3.065 & 3.860 & 4.735 \\
\hline
\end{tabular}

Source: analysis results, data was taken from Twitter from March 2 to April 15, 2020

Figure 2.

\section{Percentage of positive and negative response by categorized}

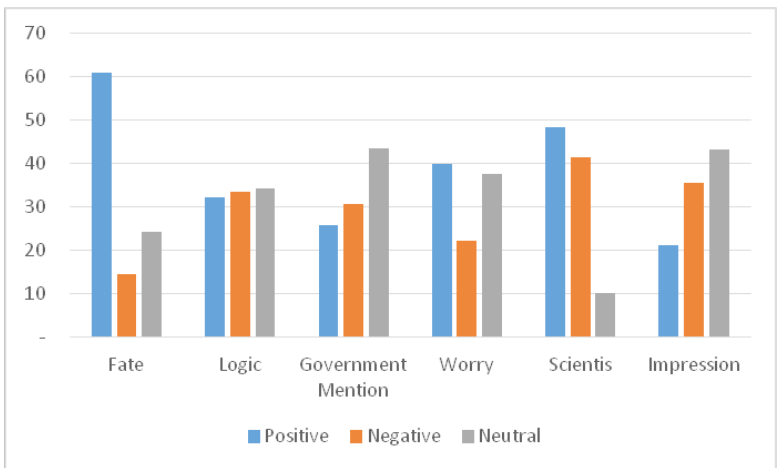

Source: analysis results, data was taken from Twitter on March 2 to April 15, 2020

\section{Word Cloud Analysis}

Figure 3. shows the issues most discussed by the community. The ten most common words are "pemerintah" (Government), "Mahfud" (name of the coordinating minister of law and security politics), "kasus" (case), "kyai" (clerics), "Anies" (name governor of Jakarta), "Formula" (Formula E), "negara" (state), "China" (country of China), "penanganan" (handlers) and "kesehatan" (health).

Figure 4. Shows words that represent people's sentiment on the issues they discussed. In the Fate category, the positive tone that most often appears is "kurniakanlah" (bless). Sentences that contain the words "kurniakanlah" such as "O God, we believe that this plague is a trial from you, bless our health," are found in the fate category with a positive tone.
Figure 3.

\section{Word cloud for various categories}

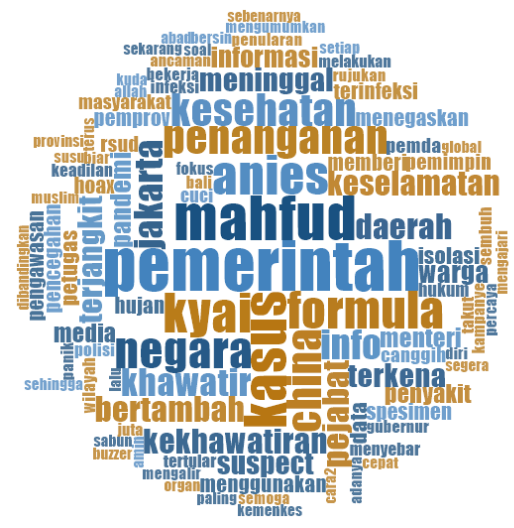

Source: analysis results, data was taken from Twitter on March 2 to April 15, 2020

While in negative tones, what appears most often are "mengabaikan" (ignoring), "tuduhan" (accusations), "tantangan" (challenges), and "teguran" (reprimands) with each having the same intensity. Sentences containing the word "ignore" for example, "people should realize that this plague is a rebuke from God, but they ignore."

In the worry category, the most positive tones that appear are the words "menggalakkan" (promote), "semprot" (spray), and "informasi" (information) while the most negative tone that appears is the word "negara" (state), "genting" (critical) and "investigasi" (investigation).

In the scientist's category, the most positive tones that emerge are the words "mengajari" (teach). The most frequent negative tones are the words "kesehatan" (health), "merebak" (spread out) dan "menyengsarakan" (misery).

\section{Government response}

Table 6 shows how the Government responded to the COVID-19 outbreak represented by accounts of 5 government agencies. Most comments were tweeted by the Ministry of Health account, then the National Disaster Management Agency, Ministry of 


\section{Figure 4.}

Word cloud public response

\begin{tabular}{|c|c|c|c|c|c|c|}
\hline Category & Fate & Logic & $\begin{array}{c}\text { Government } \\
\text { Mention }\end{array}$ & Worry & Scientist & Impression \\
\hline Positive & 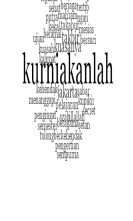 & 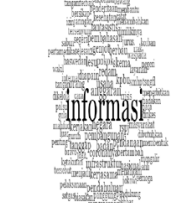 & 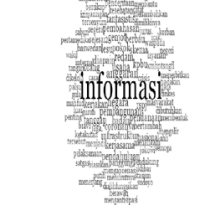 & 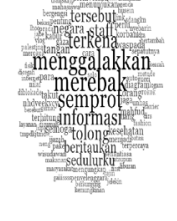 & 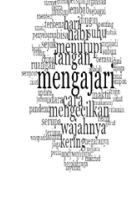 & 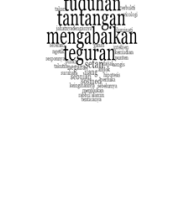 \\
\hline Negative & 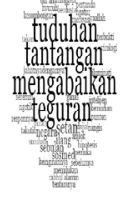 & 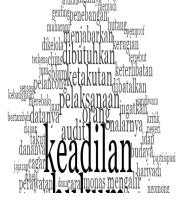 & 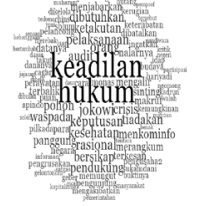 & 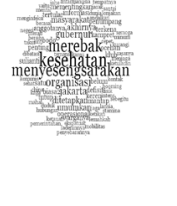 & 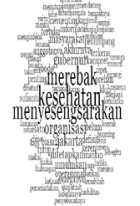 & 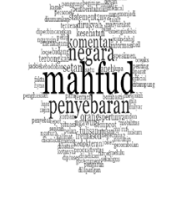 \\
\hline
\end{tabular}

Source: analysis results, data was taken from Twitter from March 2 to April 15, 2020

Table 6.

Government response

\begin{tabular}{lccc}
\hline \multicolumn{1}{c}{ Institution } & account & amount & Percentage \\
\hline President & @jokowi & 68 & $7,10 \%$ \\
BNPB (National Board for Disaster Management) & @BNPB_Indonesia & 261 & $27,24 \%$ \\
Kementerian Kesehatan (Ministry of Health) & $@$ @emenkesRI & 384 & $40,08 \%$ \\
Kementerian Keuangan (Ministry of Finance) & $@$ KemenkeuRI & 96 & $10,02 \%$ \\
Kementerian Dalam Negeri (Ministry of Internal Affairs) & @Kemendagri & 32 & $3,34 \%$ \\
Kementerian Sosial (Ministry of Social Affairs) & @KemensosRI & 117 & $12,21 \%$ \\
\hline
\end{tabular}

Source: analysis results, data was taken from Twitter from March 2 to April 15, 2020

Table 7.

Category of response

\begin{tabular}{lccccccc}
\hline \multicolumn{1}{c}{ account } & $\mathrm{I}$ & $\mathrm{E}$ & $\mathrm{O} / \mathrm{P}$ & $\mathrm{W}$ & $\mathrm{RP}$ & $\mathrm{VR}$ & $\mathrm{RM}$ \\
\hline @jokowi & 27 & 11 & 18 & 2 & 7 & 2 & 1 \\
@BNPB_Indonesia & 194 & 28 & 15 & 3 & 9 & 7 & 5 \\
@KemenkesRI & 304 & 42 & 18 & 1 & 6 & 2 & 11 \\
@KemenkeuRI & 66 & 13 & 13 & 1 & 0 & 0 & 2 \\
@Kemendagri & 18 & 8 & 4 & 1 & 1 & 0 & 0 \\
@KemensosRI & 74 & 24 & 16 & 1 & 2 & 0 & 0 \\
\hline
\end{tabular}

Source: analysis results, data was taken from Twitter on March 2 to April 15, 2020

Social Affairs, while the least tweeted account is the Ministry of Finance, the President, and the Ministry of Home Affairs.

Table 7 shows the response categories from the Government. Of the six government accounts, all accounts have the highest portion of information, while education

\section{Discussion}

The existing literature on public sentiment describes innovative practices in utilizing social media to cope with disasters (Ragini et al., 2018; Alguliyev et al., 2019; Vayansky et al., 2019; Yamada, 2020;). Yet another study illustrates the underutilized nature of social media in 
Figure 5.

Government response by categorized

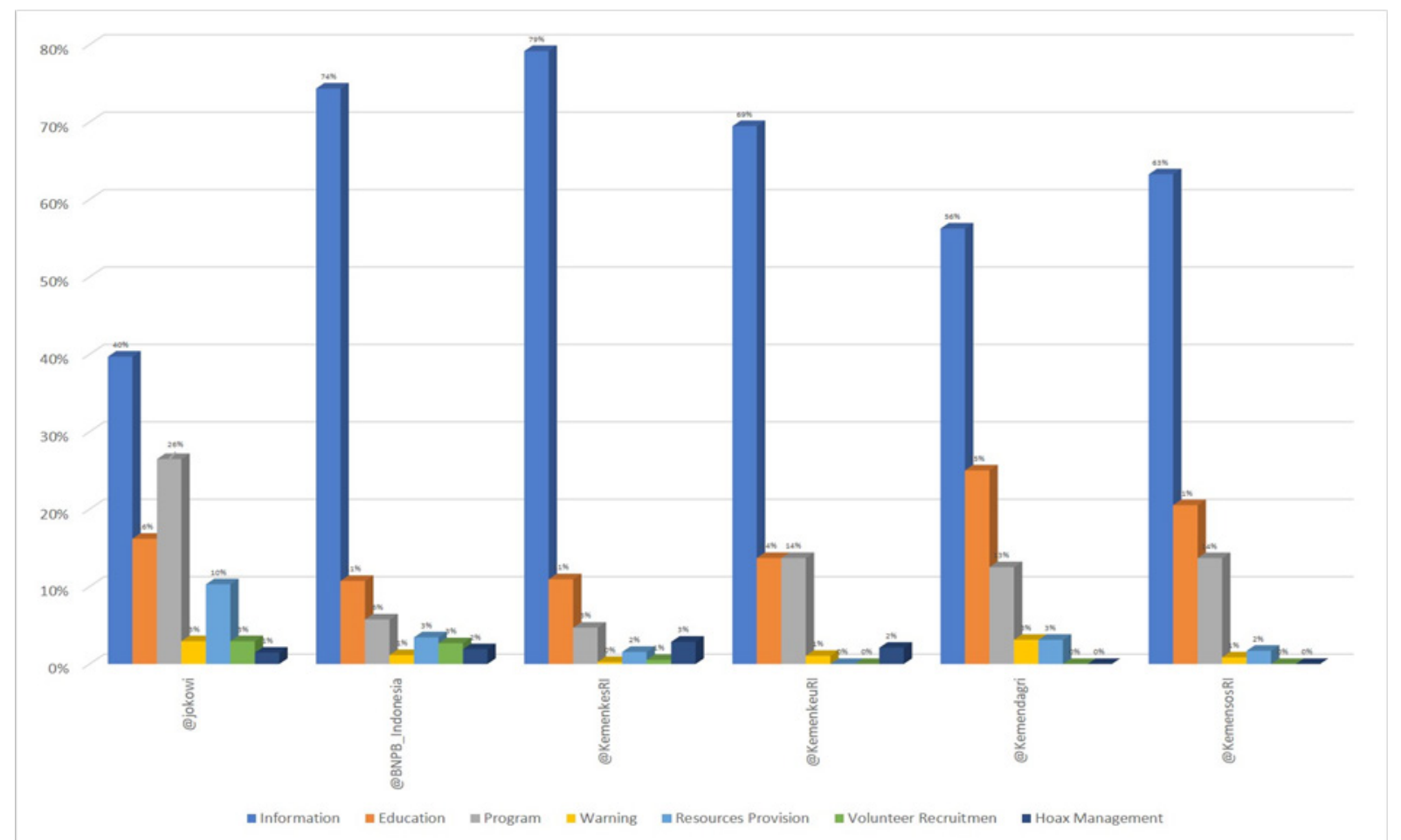

Source: analysis results, data was taken from Twitter from March 2 to April 15, 2020

emergency management (Helsloot et al., 2013), and its underuse in certain critical situations (Hunt et al., 2014). The existing studies have looked from one side of the perspective of disaster sentiment, whether from the public side or the government side. Very few have discussed the two perspectives simultaneously. To address this gap, this article discusses the public response and simultaneously examines the Government's response to the Pandemic that has occurred. The results of this study present a more comprehensive typology of messages than previously published and found that the response given by the Government will determine public sentiment towards the disaster that occurred.

All the messages analyzed were posted during a pandemic situation. This article reports that public response to the co-19 Pandemic in Indonesia is quite high. The highest is impression; it is natural considering that impression has a broader meaning, followed by government mention, worry, scientist, logic, and the lowest is fate.

What's interesting is that the public response in the category of fate is the least compared to other categories $(0.83 \%)$, which is quite surprising considering that Indonesia is a country that is considered to have a high religious climate, with $99 \%$ of the people adhering to a religion. Still, public opinion in the fate category is lowest compared to other categories. The Twitter user profile might explain this. Indonesian Twitter user profiles are, on average, have quite high levels of education (bachelor), come from cities, and have a fairly good economic level (Suprapto, 2015). The same reason can also be used to discover positive sentiment of $61 \%$, which is higher than the negative sentiment of $16 \%$. People with a high level of education and economy do not associate disaster with 
religion, and they have a positive outlook on the future.

The public response in the logic category is high compared to fate at $8.63 \%$. The research findings show that the sentiment in the logic category is balanced between positive by $32 \%$, negative by $33 \%$. It can explain that the first case of COVID-19 in Indonesia only appeared in March 2020, so that the public did not relate enough information to COVID-19. Another thing that influences may be related to the category scientist, wherein the scientist category, experts also have a divided view, and the difference is not too large between the positive sentiment of $48 \%$ and negative by $45 \%$. Statements such as "according to expert opinion, it turns out that coronavirus can cure with spices which are widely available and consumed by Indonesian people." Then responded with, "according to other experts, spice consumption has not clinically proven to cure coronavirus," showing that the response of people in the category logic is related to the opinions of experts in the scientist category.

The response of the people in the government mention category can be said to be high at $30.60 \%$. This proves that the expectation of preventive and saving measures by the Government and public attention to what the Government is doing is high. Public sentiment in the category of government mention is negative by $30 \%$. This was influenced by the readiness of the Government in dealing with the COVID-19 outbreak, especially at the beginning of the COVID-19 case. The community feels that the Government is stuttering and does not have a clear program in dealing with a pandemic. Somewhat different from the government elite in Canada, for example (Merkley, 2020) statements issued by Indonesian government officials are considered inconsistent and sometimes conflicting with one another.

Public response in the worry category is $7.07 \%$; this is a low number when viewed from the perspective of disaster, for example, compared to Chinese people who have a concerning level above 10\% (Xue Han, 2020). Public sentiment in the worry category shows that, amid worries, the public has positive sentiment over the existence of a pandemic. This can be explained that in April, despite a surge in positive cases in Indonesia, but in China as a pandemic country of origin, there has been a sharp decline in the number of cases. The public sees that with proper handling from the Government, a pandemic in Indonesia will be suppressed. Another reason for positive sentiment concerns other categories with a higher positive tone, fate, and scientists. Even though people are worried, the positive tone of those who associate disaster with religion and expert opinion affects them.

The response of people who know about a pandemic or coronavirus is $4.15 \%$. This number shows the involvement of experts or people who know disasters and coronaviruses is high. There is a difference in the sentiments of these experts on the ongoing Pandemic, although, the tone expressed is positive ( $40 \%$ versus $32 \%$ ). Differences between experts are reasonable given the emergence of the coronavirus is fast, and there are no studies that can use as a reference in overcoming coronavirus.

Public responses in the category of impressions are very diverse and have the greatest number of responses, namely $49 \%$; most of the chat in the impression tone contains comments about bad habits, help patients, want to go back to work, popularizing antipandemic, solicitation of volunteers. The sentiment of the impression category has a negative tone. The negative tone in complaints about economic conditions, complaints about quarantine, and state officials.

\section{Word cloud analysis}

From the results of the analysis of the ten words with the highest intensity, three are persona. Among them are "Mahfud" a 
coordinating minister of politics, law, and security, then "Anies" a Jakarta governor, and "Kyai" who represent religious figures. "Mahfud" appears to be a trending topic due to his controversial statements. One of them was a statement regarding the absence of coronavirus in Indonesia, which started on March 1, 2020, but 1 day later, the Government announced a positive case of COVID-19 in Indonesia. "Anies" received great attention given its position as Governor of Jakarta, and half of the number of positive cases were in Jakarta. "Kyai" received considerable attention from the public for several reasons, the first being the Support of the Indonesian Ulama Council for government programs (Majelis Ulama Indonesia)., "Mahfud" gets negative sentiment from the public, which is reasonable given the controversy of his statement. While "Anies" and "Kyai" generally get positive tones.

\section{Government response}

The Government relied on owned media to convey information incrementally and at the discretion of traditional media outlets. However, nowadays, through social media, the Government can directly reach the audience with messages of education, prevention, mitigation, and preparedness. The total of tweets from government accounts is 999 or an average of 4 tweets per day. In terms of quantity, during the need for people to get information on various things done by the Government, that number is still insufficient. The Government's response shows the lack of efforts made by the Government in absorbing public aspirations and communicating various government policies and programs to the public. Most tweets come from the Ministry of Health, with an average of 8 tweets per day. While the National Disaster Management Agency tweeted an average of 6 tweets per day, the Ministry of Social Affairs 3 tweets per day, the Ministry of Finance averaged two tweets per day, the President averaged one tweet per day, and the Ministry of Internal Affairs averaged one tweet per 2 days. Besides the use of other media besides Twitter as a government communication media, when viewed from the quantity, communication carried out by the Government has not maximized the advantages offered by Twitter compared to other social media, namely the speed of response (Rodrigues et al., 2018).

Another thing that can analyze from the Government's response is how the Government communicates pandemic countermeasures with the public. According to (Graham, Avery, \& Park, 2015) and (Wukich, 2016), government agencies face challenges in using social media to improve the effectiveness of their communication strategies. So, besides impact, practitioners are also given evidence here that crises can be better contained and managed with strategic social media use; in this case, quantity/breadth wasn't prioritized over quality/depth.

When viewed from the quality of the information conveyed, government communication with the public is dominated by information. Without reducing the importance of information, what is also important to communicate to the public at the time of a disaster are operations, warning of disaster hazards, information on mobilizing resources, recruiting volunteers, and hoax management, Sutton et al. (2014), Hughes et al. (2014), Wukich et al. (2015).

From Data can be seen that government efforts in providing education, operations, warning, mobilization of resources, recruitment of volunteers, and hoax management are still not visible. Pasa times of disaster, especially those that are massive, the ability of the Government in resources is minimal. The Government needs to invite the community to help volunteer so the community can help with handling a pandemic through national social movements. Another important thing is how the Government mobilizes resources and informs 
the public and prevents hoaxes. Reflecting on the experience of Vietnam (La et al., 2020), with sufficient and quality information, the public can discover various efforts and programs carried out by the Government. That condition will encourage synergy from all walks of life to participate to overcome the Pandemic.

\section{Conclusion}

At this time, the community has channeled their responses to various things on social media, including the COVID-19 Pandemic that occurred. The public has channeled their responses through expressions that can be categorized and measured by their sentiments. Likewise, the Government has responded and stated it on social media. The Government has tried to convey various categorized messages to be reached and accepted by the public. This article shows the diversity of public expression and sentiment and messaging strategies available to emergency managers and reports that most state agencies in Indonesia implement several types of messages, particularly Information, Education, Operating / Program, Warnings, Resources Provision, Volunteer recruitment, rumors management. However, few of the government agencies regularly adopt more interactive tactics, suggesting that more work is needed to pursue the full potential of social media in promoting risk reduction in Pandemic disaster response. Although communication efforts are not limited to social media, the superiority of using social media in disaster management must be considered by the Government.

The main contribution of this research is the step-by-step analytical development by developing public and Government categorization, which makes the findings more reflective of reality. In addition, this study emphasizes that social media can help understand public attitudes and government responses to disasters, which can increase situational awareness and help accelerate disaster response and support post-disaster management. The evaluation results show that both models are accurate and suitable for understanding public opinion and communications made by the Government. However, this study has a limitation, namely in the sample frame used, where data was only obtained for only one month during the early days of COVID-19 cases in Indonesia, so it could not capture the public and government responses when the pandemic was increasing. Therefore, further research needs to expand the observation period and media other than Twitter, such as websites, Instagram, and YouTube, so the results are more comprehensive than this research.

\section{References}

Ahmed, S. F., Quadeer, A. A., \& McKay, M. R. (2020). Preliminary identification of potential vaccine targets for the COVID-19 Coronavirus (SARS-CoV-2) Based on SARS-CoV Immunological Studies. Viruses, 12(3). https://doi.org/10.3390/ v12030254

Ahmed, W., Vidal-Alaball, J., Downing, J., \& Seguí, F. L. (2020). COVID-19 and the $5 \mathrm{G}$ conspiracy theory: Social network analysis of twitter data. Journal of Medical Internet Research, 22(5), 1-9. https://doi. org/10.2196/19458

Akinboade, O. A., Kinfack, E. C., \& Mokwena, M. P. (2012). An analysis of citizen satisfaction with public service delivery in the Sedibeng district municipality of South Africa. International Journal of Social Economics, 40(5), 458-478 https://doi. org/10.1108/03068291211199350

Al Tamimi, H., \& Dwivedi, R. (n.d.). Critical Success Factor of Promoting Research and Innovation Interest among University Students: A Study of UAE/Dubai. FINAL CONFERENCE PROCEEDINGS, 34.

Alguliyev, R. M., Aliguliyev, R. M., \& Niftaliyeva, G. Y. (2019). Extracting 
social networks from e-government by sentiment analysis of users' comments. Electronic Government, 15(1), 91-106. https://doi.org/10.1504/EG.2019.096576

Amrullah, A. Z., Sofyan Anas, A., \& Hidayat, M. A. J. (2020). Analisis Sentimen Movie Review Menggunakan Naive Bayes Classifier Dengan Seleksi Fitur Chi Square. Jurnal Bumigora Information Technology (BITe), 2(1), 40-44. https://doi. org/10.30812/bite.v2i1.804

Branz, L., \& Brockmann, P. (2018). Sentiment Analysis of Twitter Data. Proceedings of the 12th ACM International Conference on Distributed and EventBased Systems - DEBS '18. https://doi. org/10.1145/3210284.3219769

Caddy, S. (2020). Developing a vaccine for covid-19. BMJ (Clinical Research Ed.), 369(May), m1790. https://doi.org/10.1136/ bmj.m1790

de Albuquerque, J. P., Herfort, B., Brenning, A., \& Zipf, A. (2015). A geographic approach for combining social media and authoritative data towards identifying useful information for disaster management. International Journal of Geographical Information Science, 29(4), 667-689. https://doi.org/10.1080/1365881 6.2014 .996567

De Salazar, P. M., Niehus, R., Taylor, A., Buckee, C. O., \& Lipsitch, M. (2020). Using predicted imports of 2019-nCoV cases to determine locations that may not be identifying all imported cases. medRxiv, 2020.02.04.20020495. https://doi. org/10.1101/2020.02.04.20020495

Dhyani, S., Thakur, G. S., \& Sahu, Y. (2019). Assorted sentiment analysis model for natural crisis response and recovery using big data driven technology. International Journal on Emerging Technologies, 10(4), 345-353.

Gao, J., Tian, Z., \& Yang, X. (2020). Breakthrough: Chloroquine phosphate has shown apparent efficacy in treatment of COVID-19 associated pneumonia in clinical studies. BioScience Trends, 14(1), 72-73. https://doi.org/10.5582/ BST.2020.01047

Graham, M. W., Avery, E. J., \& Park, S. (2015). The role of social media in local government crisis communications. Public Relations Review, 41(3), 386-394. https:// doi.org/10.1016/j.pubrev.2015.02.001

Gunawan, B., Pratiwi, H. S., \& Pratama, E. E. (2018). Sistem Analisis Sentimen pada Ulasan Produk Menggunakan Metode Naive Bayes. Jurnal Edukasi Dan Penelitian Informatika (JEPIN), 4(2), 113. https://doi. org/10.26418/jp.v4i2.27526

Han, X., \& Wang, J. (2019). Using social media to mine and analyze public sentiment during a disaster: A case study of the 2018 Shouguang city flood in China. ISPRS International Journal of Geo-Information, 8(4). https://doi.org/10.3390/ijgi8040185

Han, X., Wang, J., Zhang, M., \& Wang, X. (2020). Using social media to mine and analyze public opinion related to COVID-19 in China. International Journal of Environmental Research and Public Health, 17(8). https://doi.org/10.3390/ ijerph17082788

Hughes, A. L., St. Denis, L. A., Palen, L., \& Anderson, K. M. (2014). Online public communications by police \& fire services during the 2012 Hurricane Sandy. Conference on Human Factors in Computing Systems - Proceedings, 1505-1514. https:// doi.org/10.1145/2556288.2557227

Kaila, R.P. \& Prasad, A. V. K. (2020). Informational Flow on Twitter - Corona Virus Outbreak Topic. International Journal of Advanced Research in Engineering and Technology ;11(3), 128-134.

La, V. P., Pham, T. H., Ho, M. T., Nguyen, M. H., Nguyen, K. L. P., Vuong, T. T., ... Vuong, Q. H. (2020). Policy response, social media and science journalism for the 
sustainability of the public health system amid the COVID-19 outbreak: The vietnam lessons. Sustainability (Switzerland), 12(7). https://doi.org/10.3390/su12072931

Li, X., Geng, M., Peng, Y., Meng, L., \& Lu, S. (2020). Molecular immune pathogenesis and diagnosis of COVID-19. Journal of Pharmaceutical Analysis, 10(2), 102-108. https://doi.org/10.1016/j.jpha.2020.03.001

Liu, C., Zhou, Q., Li, Y., Garner, L. V., Watkins, S. P., Carter, L. J., ... Albaiu, D. (2020). Research and Development on Therapeutic Agents and Vaccines for COVID-19 and Related Human Coronavirus Diseases. ACS Central Science, 6(3), 315-331. https:// doi.org/10.1021/acscentsci.0c00272

Maylawati, D. S., Mudyawati, M. N., Wahisyam, M.H., \& Maulana, R. A. (2021).Comparison of Classification Algorithms for Sentiment Analysis on Movie Comments. Gunung Djati Conference Series, 3, 68-80.

Merkley, E., Bridgman, A., Loewen, P. J., Owen, T., Ruths, D., \& Zhilin, O. (2020). A Rare Moment of Cross-Partisan Consensus: Elite and Public Response to the COVID-19 Pandemic in Canada. Canadian Journal of Political Science, (May), 1-8. https://doi. org/10.1017/S0008423920000311

Muliawaty, L., Alamsyah, K., Salamah, U., \& Maylawati, D. S. (2019). The concept of big data in bureaucratic service using sentiment analysis. International Journal of Sociotechnology and Knowledge Development. https://doi.org/10.4018/IJSKD.2019070101

Olapegba, P. O., Iorfa, S. K., Kolawole, S. O., Oguntayo, R., Gandi, J. C., Ottu, I. F. A., \& Ayandele, O. (2020). Survey data of COVID-19-related Knowledge, Risk Perceptions and Precautionary Behavior among Nigerians. Data in Brief, 30, 105685. https://doi.org/10.1016/j.dib.2020.105685

Pastor, C. K. L. (2020). Sentiment analysis of Filipinos and effects of extreme community quarantine due to coronavirus (COVID-19) Pandemic. Journal of
Critical Reviews, 7(7), 91-95. https://doi. org/10.31838/jcr.07.07.15

Prompetchara, E., Ketloy, C., \& Palaga, T. (2020). Immune responses in COVID-19 and potential vaccines: Lessons learned from SARS and MERS epidemic. Asian Pacific Journal of Allergy and Immunology, 38(1), 1-9. https://doi.org/10.12932/AP200220-0772

Putra, S. J., Khalil, I., Gunawan, M. N., Amin, R. I., \& Sutabri, T. (2018). A hybrid model for social media sentiment analysis for Indonesian text. ACM International Conference Proceeding Series, 297-301. https://doi.org/10.1145/3282373.3282850

Ragini, J. R., Anand, P. M. R., \& Bhaskar, V. (2018). Big data analytics for disaster response and recovery through sentiment analysis. International Journal of Information Management, 42(September 2017), 13-24. https://doi.org/10.1016/j. ijinfomgt.2018.05.004

Rekha, V., Raksha, R., Patil, P., Swaras, N., \& Rajat, G. L. (2019). Sentiment Analysis on Indian Government Schemes Using Twitter data. 2019 International Conference on Data Science and Communication, IconDSC 2019, 1-5. https://doi.org/10.1109/ IconDSC.2019.8817036

Rodrigues, A. P., Rao, A., \& Chiplunkar, N. N. (2018). Sentiment Analysis of Real Time Twitter Data Using Big Data Approach. 2nd International Conference on Computational Systems and Information Technology for Sustainable Solutions, CSITSS 2017, 1-6. https://doi.org/10.1109/ CSITSS.2017.8447656

Ruhyana, N. (2019). Analisis Sentimen Terhadap Penerapan Sistem Plat Nomor Ganjil / Genap Pada Twitter Dengan Metode Klasifikasi Naive Bayes. Jurnal IKRA-ITH Informatika, 3(1), 94-99.

Shull, P. B., Jiang, S., Zhu, Y., \& Zhu, X. (2019). Hand gesture recognition and finger angle estimation via wrist- 
worn modified barometric pressure sensing. IEEE Transactions on Neural Systems and Rehabilitation Engineering, 27(4), 724-732. https://doi.org/10.1109/ TNSRE.2019.2905658

Sohrabi, C., Alsafi, Z., O'Neill, N., Khan, M., Kerwan, A., Al-Jabir, A., ... Agha, R. (2020). World Health Organization declares global emergency: A review of the 2019 novel coronavirus (COVID-19). International Journal of Surgery, 76, 71-76. https://doi.org/10.1016/j.ijsu.2020.02.034

St. Denis, L. A., Palen, L., \& Anderson, K. M. (2014). Mastering social media: An analysis of Jefferson County's communications during the 2013 Colorado floods. ISCRAM 2014 Conference Proceedings 11th International Conference on Information Systems for Crisis Response and Management, (May), 737-746.

Sutton, J., Spiro, E. S., Johnson, B., Fitzhugh, S., Gibson, B., \& Butts, C. T. (2014). Warning tweets: serial transmission of messages during the warning phase of a disaster event. Information Communication and Society, 17(6), 765-787. https://doi.org/10. 1080/1369118X.2013.862561

Thompson, C. J., Barber, K., \& Bourget, E. M. (2018). STEAM (Science, Technology, Engineering, Art, and Mathematics) Education and Teachers' Pedagogical Discontentment Levels. PEOPLE: International Journal of Social Sciences, 4(3). Vayansky, I., Kumar, S. A. P., \& Li, Z. (2019). An Evaluation of Geotagged Twitter Data during Hurricane Irma Using Sentiment Analysis and Topic Modeling for Disaster Resilience. International Symposium on Technology and Society, Proceedings, 2019-November, 1-6. https:// doi.org/10.1109/ISTAS48451.2019.8937859

Wang, Z., \& Ye, X. (2018). Social media analytics for natural disaster management. International Journal of Geographical Information Science, 32(1), 49-72. https:// doi.org/10.1080/13658816.2017.1367003

Worldmeter. (2020). Indonesia Corona Viruses Case. Retrieved January 2, 2021, from https://www.worldometers.info/ coronavirus/country/indonesia/

Wu, X., Zhu, X., Wu, G. Q., \& Ding, W. (2014). Data mining with big data. IEEE Transactions on Knowledge and Data Engineering. https://doi.org/10.1109/ TKDE.2013.109

Wu, Z., \& McGoogan, J. M. (2020). Characteristics of and important lessons from the coronavirus disease 2019(COVID-19) outbreak in China. Jama, 323(13), 1239-1242. https://doi. org/10.1001/jama.2020.2648

Wukich, C. (2016). Government Social Media Messages across Disaster Phases. Journal of Contingencies and Crisis Management, 24(4), 230-243. https://doi.org/10.1111/14685973.12119

Yamada, K. (2020). Public response to news reports on the Mount Kusatsu-Shirane volcanic eruption: A content analysis of online reader comments. International Journal of Disaster Risk Reduction, 43(July 2019), 101388. https://doi.org/10.1016/j. ijdrr.2019.101388 